Literature review

\title{
Pathophysiology and management of gustatory rhinitis
}

\author{
Nina Irawati, Shally Adhina Putri \\ Department of Otorhinolaryngology Head and Neck Surgery, \\ Faculty of Medicine Universitas Indonesia/Dr. Cipto Mangunkusumo Hospital, \\ Jakarta
}

\begin{abstract}
Background: Gustatory rhinitis is a syndrome that causes symptoms of annoying rhinorrhea, occurring immediately after consuming solid or liquid foods which are hot and /or spicy. Usually starts within a few minutes after the ingestion of the foods involved, and is not associated with itching, sneezing, nasal congestion or facial pain. Purpose: To discuss the pathophysiology and proper management of gustatory rhinitis. Literature Review: Recent studies suggest that gustatory rhinitis is likely associated with phenomenon of neurogenic inflammation. The ingestion of spicy foods caused the stimulation of trigeminal sensory nerve endings located in the upper part of the aerodigestive track. Sensory nerve stimulation seems to be correlated with an activation of post ganglionic cholinergic muscarinic parasympathetic fibers and sensitive to atropine. Conclusion: The initial management of gustatory rhinitis is avoiding the trigger foods. Using combination of topical steroid and anticholinergic intranasal had been proven more effective to treat the rhinorrhea caused by gustatory rhinitis than administration of single drug.
\end{abstract}

Keywords: gustatory rhinitis, rhinorrhea, topical intranasal

\begin{abstract}
ABSTRAK
Latar belakang: Rinitis gustatori adalah sindroma yang menimbulkan gejala rinore yang mengganggu, sesaat setelah mengonsumsi makanan padat atau cair, yang bersifat pedas dan/atau berempah. Biasanya dimulai dalam beberapa menit setelah menelan makanan tersebut, dan tidak disertai dengan gatal, bersin, hidung tersumbat atau nyeri wajah. Tujuan: Untuk membahas patofisiologi dan tatalaksana yang tepat pada rinitis gustatori. Tinjauan Pustaka: Sejumlah studi terbaru mendapatkan rinitis gustatori berkaitan dengan fenomena inflamasi neurogenik. Proses menelan makanan pedas dapat menyebabkan stimulasi ujung saraf sensorik trigeminal yang terletak di jalur aerodigestif bagian atas. Stimulasi saraf sensorik tersebut berkaitan dengan pengaktifan serabut saraf parasimpatik muskarinik kolinergik post ganglion yang sensitif terhadap atropin. Kesimpulan: Tatalaksana awal yang dapat dilakukan untuk mengatasi rinitis gustatori adalah menghindari makanan pemicu. Kombinasi penggunaan antikolinergik intranasal dan steroid topikal, secara profilaksis atau sebagai terapi telah terbukti lebih efektif untuk mengatasi rinore akibat rinitis gustatori dibandingkan pemberian masingmasing obat tersendiri.
\end{abstract}

Kata kunci: rinitis gustatori, rinore, intranasal topikal

Correspondence address: Shally Adhina Putri. Department of Otolaryngology Head and Neck Surgery, Faculty of Medicine Universitas Indonesia/Dr. Cipto Mangunkusumo Hospital, Jakarta. Email: shally.adhina@gmail.com. 


\section{INTRODUCTION}

Gustatory rhinitis is a syndrome that causes irritating rhinorrhea symptoms shortly after consuming hot and/or spicy foods. It usually starts within minutes of ingesting the food involved. This symptom is not accompanied by complaints of sneezing, nasal congestion, itching, and facial pain. Gustatory rhinitis is considered a non-immunological reaction.

Patients with gustatory rhinitis do not have impaired taste or smell, and there are no certain predisposing factors such as gender, ethnicity, or individual atopy. The initial treatment for gustatory rhinitis is to avoid trigger foods. The concomitant use of topical intranasal anticholinergic and corticosteroid had shown to be both prophylactic and therapeutic, and more effective than administration of either drugs alone. ${ }^{1}$

The purpose of this article is to discuss gustatory rhinitis and its management.

\section{LITERATURE REVIEW}

Gustatory rhinitis is rhinorrhea occurring after ingestion of irritating food, most often hot or spicy. It is considered that this phenomenon is most likely caused by stimulation of trigeminal sensory nerve endings located at the upper aerodigestive track.

Humans have 4 types of tongue papillae: fungiform, foliate, and circumvallate papillae for sensing taste, while filiform papillae transduce touch, temperature, and nociception. The fungiform papillae are mushroom-shaped structures that protrude from the surface of the tongue. Humans have on average 195 human fungiform papillae, $87 \%$ of which are located at the anterior 2 $\mathrm{cm}$ of the tongue. Foliate papillae are folds on the lateral sides of the tongue containing over 100 taste buds. Circumvallate papillae form an inverted $\mathrm{V}$ at the posterior of the tongue. There are over 100 taste buds in the circumvallate papillae. ${ }^{2}$

The human olfactory mucosa is a pseudostratified columnar epithelium with a highly cellular lamina propria. This epithelium has four different cell types: ciliated olfactory receptors, supporting cells, microvillar cells and basal cells. The nasal mucosa is located in the nasal cavity. The surface of the nasal cavity is about $150 \mathrm{~cm}^{2}$ and the total volume is about $15 \mathrm{ml}$. The surfaces of the nasal cavity and paranasal sinuses are lined with continuous mucosa of various properties and thicknesses. $^{3}$

The nose has function as defense and regulatory system, requiring rapid response to a variety of physical and chemical stimuli. Therefore, the nasal has a complex nervous system, namely the sensory, parasympathetic, and sympathetic nervous systems. The sensory nerves send signals from the mucosa, producing sensations, such as itching and sneezing. Meanwhile, the parasympathetic and sympathetic nerves affect the structure of the gland and the nasal vascular system.

Nerve function can increase if there is an inflammation of the mucosa, allergic reactions, or non-allergic rhinitis. This increase occurs in various reflex pathways, which trigger an exaggerated response (hyper responsiveness), namely the occurrence of neurogenic inflammation, a condition in which neuropeptides are released on antidromic stimulation of nociceptive nerve fibers. The hyper responsiveness mechanism is not yet understood, but it is suspected that there is a role for inflammatory mediators such as neurotrophins (nerve growth factors).

In human body, it is known that substance P could increase the accumulation of allergeninduced eosinophils. Neurokinin- 1 receptors, activated by substance P and neurokinin A, are present in the human nasal glands and epithelium. Meanwhile, the neurokinin 2 receptors are only activated by neurokinin 
A, which is found in the nasal mucosa blood vessels. ${ }^{4,5}$

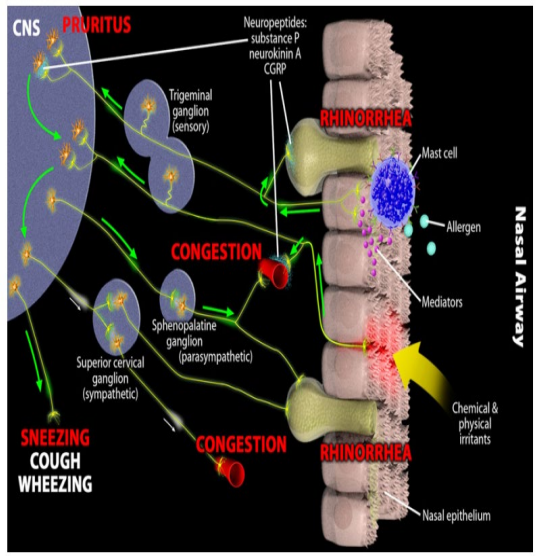

Figure 1. Nasal symptom innervation pathway, ${ }^{4}$

Neuropeptides of sensory nerve consists of tachykinin (substance P and neurokinin A) Calsitonin Gene-Retalated Peptide (CGRP). The release of neuropeptides by sensory nerve endings results in vasodilation and increased vascular permeability. ${ }^{4,5}$

The preganglionic fibers of parasympathetic nerve follow the major superficial petrosus nerve and the vidian nerve synapses in the sphenopalatine ganglion. The preganglionic parasympathetic nerves release acetylcholine and possibly other neurotransmitters that act on the nicotinic receptor ion channels on postganglionic neurons. ${ }^{1,5}$

Postganglionic fibers spread to the nasal mucosa via the branches of the posterior nasal nerves. They supply the serous and mucous glands, arteries, veins, and arteriovenous anastomoses. These fibers also release acetylcholine, and some postganglionic fibers contain neuropeptides, such as Vasoactive Intestinal Peptide (VIP), histidine methionine peptide, and histidine valine peptide, and Nitric Oxide (NO) synthase, which produces Nitric Oxide (NO). These neuropeptides cause glandular hypersecretion, vasodilation, and dilation of the sinusoids in the nasal mucosa.
The parasympathetic nerve activation is very sensitive to atropine and parasympathomimetics.

The sympathetic nerves in the human nose originate from the preganglionic fibers in the thoracolumbar region of the spinal cord, which pass through the vagosympathetic trunk and into the superior cervical ganglion. Postganglionic fiber forms the deep petrosus nerve which joins the major superficial nerve to form the vidian nerve. Sympathetic fibers can reach the nose from the carotid plexus through the branches of the trigeminal nerve.

Neuropeptides Y (NPY), together with norepinephrine are located in the arteriolar walls of the human nasal mucosa and arteriovenous anastomosis. NPY has the same effect as norepinephrine which can cause vasoconstriction and is reported to be more effective than oxymetazoline, as a topical nasal decongestant, for reducing symptoms of nasal obstruction, nasal airflow resistance, and mucus counts. ${ }^{1,4}$

Rhinitis is generally divided into three categories, which are allergic rhinitis, infectious rhinitis, and non-allergic rhinitis. Allergic rhinitis is an IgE-mediated inflammation of the nose triggered by various allergens such as house dust mites, pollen, and mold. Allergic rhinitis is the most common form of non-infectious rhinitis, especially at a young age. ${ }^{5}$

Allergic Rhinitis and its Impact on Asthma (ARIA) divides complaints of allergic rhinitis into intermittent (when symptoms appear less than four days a week or less than four consecutive weeks) and persistent (symptoms occur for more than four days a week and more of four consecutive weeks). The severity of symptoms was categorized into mild (did not cause sleep disturbances, disruption to activities, school or work) and moderate-severe (caused disturbances in sleep, activity, school or work). ${ }^{5,6,7}$

Infectious rhinitis occurs with symptoms of nasal congestion, discharge, facial pain, 
and smelling disorders. Infectious rhinitis can be acute or chronic depending on the onset of the disease. Infectious rhinitis can be caused by bacteria, viruses, and fungi. Comorbid factors such as diabetes mellitus, nutritional status, and immunocompromised conditions could contribute in the initiation of infection.

Table 1. Classification of rhinitis ${ }^{5,6,7}$

\begin{tabular}{l}
\hline Allergic \\
Intermittent \\
Persistent \\
\hline Infections \\
$\quad$ Bacterial \\
Virus \\
$\quad$ Fungus \\
Non allergic \\
Idiopathic \\
$\quad$ - Non-infectious non- allergic rhinitis \\
$\quad$ - Non-allergic non-infectious perennial \\
$\quad$ rhinitis \\
$\quad$ - Perennial non-allergic rhinitis \\
$\quad$ - Gustatory rhinitis \\
NARES (Non-Allergic Rhinitis with \\
Eosinophilia Syndrome) \\
Occupational rhinitis \\
Drug-induced Rhinitis \\
$\quad$ - Neurogenic \\
$\quad$ - Inflamation \\
$\quad$ - Idiopathic \\
Hormonal rhinitis \\
Rhinitis medicamentosa \\
Vasomotor rhinitis \\
Atrophic rhinitis \\
Systemic disease \\
Geriatric rhinitis \\
\hline
\end{tabular}

Non allergic rhinitis (NAR) is generally described as a chronic nasal symptom without allergic factors and infections as a cause. Non allergic rhinitis is not mediated by IgE. There are complaints of nasal congestion and clear rhinorrhea, but sneezing and itching of the nose or eyes are less common. Non allergic rhinitis is usually caused by weather change, food, hormones, smoking, or changes in air pressure. ${ }^{6}$

Vasomotor rhinitis is the most common type of non allergic rhinitis. Reactivity of the nasal mucosa is a balance between the sympathetic and parasympathetic systems, and it regulates vascularization and glandular expression. Autonomic dysfunction is significant in vasomotor rhinitis. Neuropeptides, nitric oxide, ozone, smoking, and other environmental factors and gastroesophageal reflux have been linked to vasomotor rhinitis. ${ }^{6}$

Atrophic rhinitis formerly is often associated with Klebsiella ozaena bacterial infection, but nowadays is seen more frequently as a result of aggressive surgery, trauma, granulomatous disease, and radiation therapy and is also associated with the aging process. ${ }^{6}$

\section{GUSTATORY RHINITIS}

Gustatory rhinitis is a syndrome that causes irritating rhinorrhea symptoms, shortly after consuming hot and/or spicy foods. This happens because it contains capsaicin which can stimulate the sensory nerves to produce tachykinin and other neuropeptides. ${ }^{1}$

The exact pathophysiological mechanisms of gustatory rhinitis are still unknown. According to some experts, the symptoms of gustatory rhinitis are most likely related to neurological cascade. Rhinorrhea that occurs is due to reflex activation of the submucosal glands. By using the provocation of multiple stimuli, the secretory response can be measured in both nostrils. These stimuli include histamine, allergens, cold air, hypertonic solutions, capsaicin or bradykinin. ${ }^{5}$

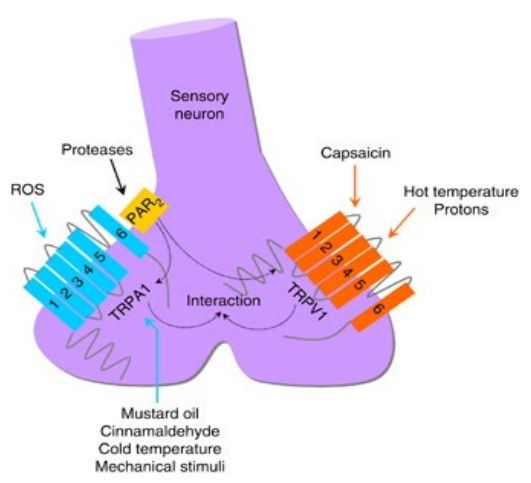

Figure 2. Transient potential vanilloid receptors, ${ }^{7}$ 
Pathophysiology and management of gustatory rhinitis

Hot and spicy foods contain capsaicin (8-methyl-n-vanillyl-6 nonenamide). Capsaicin is an active substance in red chilies and paprika components, which can stimulate afferent sensory nerves in the oral mucosa and oropharynx. In addition, capsaicin also stimulates and regulates the Vanilloid Transient Potential 1 (TRPV1) receptors at the maxillary branch (V2) trigeminal nerve endings and stimulates afferent sensory nerve fibers, such as $\mathrm{C}$ and $\mathrm{A}$ fibers, which produce a burning sensation. Besides, afferent sensory nerves trigger a neurogenic response in the form of neuropeptide release (substance $P$, neurokinin A, and CGRP) through antidromic reflexes. ${ }^{4,7}$

After stimulation of afferent sensory nerves, reflex arcs are initiated to stimulate the parasympathetic efferent sensory nerves in the nasal mucosal glands, resulting in parasympathetic hyperactivity through orthodromic reflexes that trigger neurogenic responses in the form of neuropeptides (Acetylcholine, VIP and NO) which cause excessive rhinorrhea. ${ }^{1,4}$

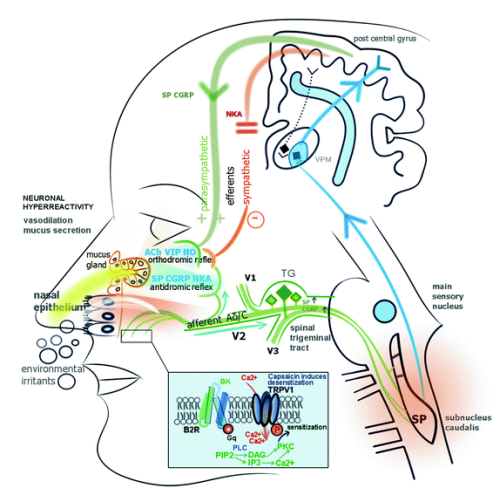

Figure 5. Neural hyperreactivity mechanism, ${ }^{8}$

In provocation with high doses of capsaicin, there is extravasation of blood vessels, entry of inflammatory substances, and release of neuropeptides trigger edema, leukocyte infiltration, and immune cell activation including lymphocytes, eosinophils, mast cells, and macrophages. This is what is called the neurogenic inflammatory phenomenon of the nasal mucosa. ${ }^{5,8}$

\section{Management of gustatory rhinitis}

\section{Nasal washing}

Nasal washing with $0.9 \%$ isotonic $\mathrm{NaCl}$ solution has also been found to be a helpful therapy in patients with rhinorrhea. Several randomized controlled studies on saline irrigation have shown a safe, effective, welltolerated use in inflammatory nasal disease. Washing the nose with isotonic solutions has been shown to be very helpful because it can clean mucus, increase the movement of cilia in the nasal mucosal epithelium, and protect the nasal mucosa. A Cochrane study in 2007 with a randomized controlled trial concluded that nasal washing was very effective as therapy with minimal side effects and could be included as an additional therapy for rhinitis. Patients are advised to wash their nose at least $2 \times 30 \mathrm{ml}$ routinely. ${ }^{5}$

Another thing that can be performed is to maintain a diet by drinking lots of fluids such as mineral water, juices, caffeine-free drinks, and avoiding provocative foods, especially hot and spicy. It could also prevent gustatory rhinitis. $^{7}$

\section{Intranasal anticholinergics}

Anticholinergic class drugs (atropine) have a good effect on patients with gustatory rhinitis. Ipratropium bromide as a topical anticholinergic work locally to effectively control rhinorrhea, nasal obstruction, postnasal drip, and sneezing. Intranasal anticholinergic can be used as prevention (before eating the irritating food) or therapy (after rhinorrhea). Ipratropium has several local side effects. Epistaxis and nasal dryness may occur, but the incidence is usually reduced if not used long-term. . $^{5,10,11}$

\section{Intranasal Steroids}

Topical intranasal steroids are generally well tolerated by individuals with gustatory 
rhinitis. These drugs can suppress the local inflammatory response caused by vasoactive mediators that can inhibit phospholipase $\mathrm{A} 2$, and can also reduce acetylcholine receptor activity, lowering inflammatory cells including basophils, eosinophils, and mast cells. The effectiveness of using this drug depends on the level of adherence to its use, and the maximum effect will be obtained in 1-2 weeks. The combination of ipratropium bromide and intranasal corticosteroid is more effective than single-use..$^{5,11}$

\section{Intranasal Capsaicin}

Topical intranasal application of capsaicin is considered to be effective in reducing longterm symptoms in nonallergic rhinitis. Type $\mathrm{C}$ fibers are very sensitive to capsaicin. When exposed to capsaicin, the amount of sensory peptides released is higher than the number of neuropeptides available, resulting in a desensitization process. This desensitization of sensory nerve endings explains the response of individuals in terms of tolerating the spicy or hot food they consume..$^{5,8}$

In one study, giving one spray every five hours for 2-3 days over two weeks had good results and can be repeated if relapse occurs. Although further study is needed, intranasal capsaicin may be a treatment option for difficult-to-control gustatory rhinitis and shown to be beneficial. ${ }^{6,8}$

\section{Resection of the Posterior Nasal Nerve}

Gustatory rhinitis can be treated prophylactically by the use of topical atropine, but sometimes the patient preferred to undergo radical therapy such as and a resection of the posterior nasal nerve, which innervating the nasal submucosal gland in order to reduce the hyperrhinorrhea. The surgical resection of the posterior nasal nerve may be an effective treatment for gustatory rhinorrhea. ${ }^{12}$

\section{DISCUSSION}

Gustatory rhinitis is a syndrome that causes irritating symptoms of rhinorrhea, shortly after consuming hot or spicy foods. It usually starts within minutes of ingesting the food and is not accompanied by itching, sneezing, nasal congestion or facial pain. ${ }^{1}$ Rhinorrhea can occur on one or both sides of the nose. A wide variety of foods have been reported to cause rhinorrhea symptoms. According to some researches the variation could be between I to 102 types of food. ${ }^{13}$

The case of gustatory rhinitis caused by hot and/or spicy food has been reported by $49 \%-73 \%$ patients. ${ }^{1}$ The most common foods that cause gustatory rhinitis contained capsaicin, an irritant found in all types of chili (red chilies, radishes, cayenne pepper), tabasco sauce, and black pepper. Other chemical irritants such as onions, vinegar, or mustard had also been reported to cause gustatory rhinitis. ${ }^{1,8,10}$

Gustatory rhinitis can cause an impaired quality of life. However, only a few studies had explored into this problem. Nearly half of gustatory rhinitis patients $(46 \%)$ stated that they have never been bothered by the complaints caused, and $65 \%$ of patients have never avoided gustatory rhinitis trigger foods. In another study, it was stated that around $1-2 \%$ of patients said they were very disturbed by the symptoms, and even caused embarrassment when they went out to eat together. ${ }^{1}$

In terms of recognizing foods that involve a combination of taste and smell sensations, recognizing various inhaled substances also requires stimulation of the olfactory and trigeminal nerves. The trigeminal nerve can provide sensations from a fresh or cold taste (in response to menthol) to a burning or stinging taste (eg, ammonia and chlorine). ${ }^{9}$

There is currently no standard objective examination, compeling the diagnosis of gustatory rhinitis based on history and 
exclusion from other types of chronic rhinitis. A subjective examination that can be used to obtain a history of food selection behavior is to use a questionnaire on the food response, to observe patterns of habits in choosing and avoiding certain foods. This food reaction questionnaire can be used to determine the incidence of rhinorrhea that is resulted from consuming certain foods or drinks. ${ }^{11}$

The questionnaire consisted of 127 items divided into broad categories: meat, milk and dairy products, fruit and juices, bread and whole grains, vegetables, fats, nuts and seeds, desserts, spices, etc. Respondents assessed the incidence of rhinorrhea with a scoring system, as follows: 1 (the nose is never runny), 2 (sometimes the nose is runny), or 3 (the nose is always runny). ${ }^{6}$

For objective examination, an adapted study from Franceschini et al, confirmed the diagnosis of gustatory rhinitis by stimulating the tip of the patient's tongue with lemon juice and confirmed the occurrence of rhinorrhea. ${ }^{13}$

Raphael et al ${ }^{13}$ also performed skin tests to rule out allergic reactions in all subjects. In their study, there were two protocols; in the first protocol, the research subjects were given a nasal spray with $0.9 \% \mathrm{NaCl}$ as much as $0.3 \mathrm{ml}$, and 10 minutes later, they were given control food followed by spicy food. In the second protocol, subjects were given control food followed by spicy food, and then nasal spraying was conducted with atropine $100 \mathrm{ug}$ as much as $0.3 \mathrm{ml}$ and then given spicy food again. The results showed that all subjects who were given control food showed no symptoms, whereas after being given spicy food, the subjects experienced nasal rhinorrheas, but there were no complaints of itching, sneezing, swelling of the lips, stomach and respiratory disorders.

The initial treatment for gustatory rhinitis is avoidance of the trigger foods, especially hot and spicy foods. Nasal washing with $0.9 \%$ isotonic $\mathrm{NaCl}$ solution has also been found to be a helpful remedy in patients with gustatory rhinitis.

Anticholinergic class drugs (atropine) have a good effect. Intranasal ipratropium bromide works effectively in controlling rhinorrhea, nasal obstruction, postnasal drip, and sneezing. ${ }^{10,11}$ Topical intranasal application of capsaicin was effective in reducing long-term symptoms in nonallergic rhinitis. In one study, giving one spray every five hours for 2-3 days over two weeks had good results and can be repeated if relapse occured. ${ }^{6,8}$

Gustatory rhinitis can be treated by using medicamentous therapy, but sometimes the patient preferred to undergo radical therapy such as a resection of the posterior nasal nerve. A resection of the posterior nasal nerve innervating the nasal submucosal gland in order to reduce the hyperrhinorrhea. ${ }^{12}$

In conclusion, patients with gustatory rhinitis are advised to avoid trigger foods, especially spicy and hot foods. Patients should perform nasal washing with $0.9 \%$ isotonic $\mathrm{NaCl}$ solution regularly. Patients with severe/persistence gustatory rhinitis symptoms may use a combination of intranasal anticholinergic-steroids, or intranasal capsaicin as an alternative therapy. If the symptoms persist and patients remain hyperrhinorrhea, then radical therapy such as posterior nasal nerve resection could be considered.

\section{REFERENCE}

1. Jovancevic L, Georgalas C, Savovic S, Janjevic D. Gustatory Rhinitis. Mini reviev of Rhinology. 2010; 48(1): 7-10

2. Gravina S.A, Yep G.L, Khan M. Human Biology of Taste. Ann Saudi Med. 2013; 33(3): 217-22.

3. Escada P. Localization and Distribution of Human Olfactory Mucosa in the Nasal Cavities. Acta Med Port. 2013; 26(3): 200-7. 
4. Sarin S, Undem B, Sanico A. The Role of the Nervous System in Rhinitis. J Allergy Clin Immunol. 2006 Nov; 118(8): 999-1014.

5. Tran NP, Vickery J, Blaiss MS. Management of rinitis: allergic and non-allergic. Allergy Asthma Immunol Res. 201; 3(3): 148-56.

6. Chan T.V. Non Allergic Rhinitis. In: Bailey's Head and Neck Surgery Otolaryngology. $5^{\text {th }}$ ed. $1^{\text {st }}$ vol. Philadelphia: Lippincott Williams and Wilkins; 2014. p. 469-85.

7. Varshney J, Varshney H. Allergic Rhinitis: an Overview. Indian J Otolaryngol Head Neck Surg. 2015; 67(2): 143-9.

8. Singh U, Bernstein JA. Intranasal Capsaicin in Management of Nonallergic (Vasomotor) Rhinitis. In: Capcaisin as a Theurapetic Molecule. 68 ${ }^{\text {th }}$ vol. Basel: Springer; 2014. p.147-70.

9. Vianna F. Chemosensory Properties of the Trigeminal System. J Neurosci. 2011; 2(1): $38-50$.

10. Scrupa M.D, Kaliner M.A. Non-allergic Rhinitis: Clinical Importance, Diffrential Diagnosis and Effective Treatment Recommendations. World Allergy Organ J. 2009; 2(3): 20-5

11. Pinar E, Eryigit O, Oncel S, Calli C, Yilmaz O, Yuksel H. Efficacy of nasal corticosteroid alone or combined with antihistamines or montelukast in treatment of allergic rinitis. Auris Nasus Larynx. 2008; 35(1): 61-4.

12. Ang YY, Kawano K, Saito T, Kasai M, Ikeda K. Treatment of Idiopathic Gustatory Rhinorrhea by Resection of the Posterior Nasal Nerve. Tohuku J. Exp. Med. 2006; 210 (2): 165-8.

13. Raphael G, Raphael M.H, Kaliner M. Gustatory Rhinitis: A Syndrome of foodinduced rhinorrhea. J Allergy Clin Immunol. 1989; 83(1): 110-5. 